\title{
Flood Risk Mapping and Analysis Using Hydrodynamic Model HEC-RAS: A Case Study of Daraudi River, Chhepatar, Gorkha, Nepal
}

\author{
Pratibha Banstola $^{1^{*}, \text { Bidhan Sapkota }^{2}}$ \\ ${ }^{1,2}$ School of Environmental Science and Management (SchEMS), Pokhara University, Mid-Baneshwor, \\ Kathmandu, Nepal \\ *Corresponding Author (Email: lucky14.pratibha@gmail.com)
}

How to cite this paper: Banstola, $P$. and Sapkota, B. (2019). Flood Risk Mapping and Analysis Using Hydrodynamic Model HEC-RAS: A Case Study of Daraudi River, Chhepatar, Gorkha, Nepal. Grassroots Journal of Natural Resources, 2(3): 25-44. Doi:

https://doi.org/10.33002/nr2581.6853.02033

Received: 02 August 2019

Reviewed: 23 August 2019

Provisionally Accepted: 31 August 2019

Revised: 05 September 2019

Finally Accepted: 17 September 2019

Published: 30 September 2019

Copyright (C) 2019 by author(s) and

The Grassroots Institute.

This work is licensed under the Creative Commons Attribution International License (CC BY 4.0).

http://creativecommons.org/licenses/by/4.0/
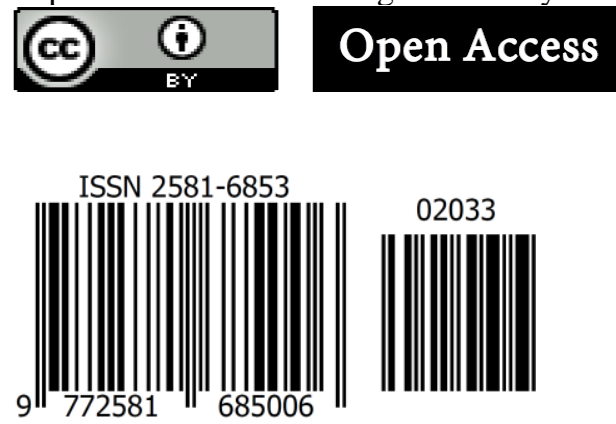

\begin{abstract}
Nepal has been ranked as one of the most multiple hazard prone countries in the world. Studies claim flood as the most common and third most deadly disaster in Nepal. It causes loss of life, casualties, financial loss and displacement. Heavy monsoon, fragile geography, constructions along the embankments and mining in the upstream riverbeds cause the river to flood. Daraudi River, one of the seven tributaries of Gandaki River, experience flood every year. Despite regular flooding, no studies have been carried out in the river zone. Hence, this study is carried out in the Chhepetar flood plain of Daraudi River basin. This article is based on a study that used HEC-RAS, HEC-GeoRAS and ArcGIS for preparation of 1D flood plain maps and WECS/DHM method to analyze the flood frequency in different return periods. The flooding in the river is found to be correlated with maximum rainfall in a year and occurs particularly between June and September every year - the period of Monsoon season in Nepal. A direct relationship between the inundation area and the flood discharge of various return periods has been identified. Plantation, bioengineering technique, dry wall construction on the river bank and different non-structural approaches of flood management have been suggested by the study for eco-restoration.
\end{abstract}

\section{Keywords}

Flood, Inundation, HEC-RAS, Risk 
Doi: https://doi.org/10.33002/nr2581.6853.02033

\section{Introduction}

Risk is the probability of harm that occurs at a place, community or a system as a result of interactions between natural or human-induced hazards and vulnerable conditions (UNDP, 2010). The impact which may occur after a disaster may be assessed by the vulnerability. It denotes how susceptibile is an individual, a community, asset or a system to the impacts of hazards (UNISDR, 2017). Flood usually denotes the overflow of water. Overflow may occur from a stream channel onto normally dry land in the alluvial plain, termed as riverine flooding; from higher-than-normal levels along the coast and in lakes or reservoirs, called coastal flooding; as well as ponding of water at or near the point where the rain fell, known as flash floods (IRDR, 2014). Cred (2018) classifies flood as hydrological disaster. Statistics show that 318 natural disasters affected 122 countries worldwide in the year 2017 alone, the impacts of which resulted in 9,503 deaths, 96 million people affected, and US\$314 billion as economic damages. Flood accounted for $38.3 \%$ of these disasters, $35 \%$ of deaths, affecting $59.6 \%$ of peoples' livelihoods and $6.2 \%$ of economic damages during the year 2017 (Cred, 2018).

Flood is the most common natural disaster in Nepal. Nepal is ranked in the list of top 20 most multi-hazard prone countries in the world and $30^{\text {th }}$ in term of flood risks (Dangal, 2014). In this research, hydrodynamic model HEC-RAS and ArcGIS software tool have been used to mapping the flood. HEC-RAS is an integrated system of software comprising a graphical user interface (GUI), separate hydraulic analysis components, data storage and management capabilities, graphics and reporting facilities. It is designed for interactive use in a multi-tasking, multi-user network environment, and is currently capable of performing 1D water surface profile calculations for steady gradual varied flow in natural or constructed channels (Brunner, 2016). A risk assessment of any event needs to take into account the geospatial characteristics of the hazard, exposure, vulnerability and coping-capacity components which can be achieved by integrating different spatial data sets and administrative non-spatial information in a GIS.

\section{Study Area}

This study was carried out in Chhepetar flood plain of Daraudi River basin. It is located in Gorkha district, province number 4 of Nepal. It lies at a distance of 15 kilometers from the Prithivi Highway and 126 kilometers from Kathmandu. The geographical location is $27^{\circ} 59^{\prime} 11.68^{\prime \prime} \mathrm{N}$ and $84^{\circ} 33^{\prime} 55.32^{\prime \prime}$ E to $28^{\circ} 2^{\prime} 8.96^{\prime \prime} \mathrm{N}$ and $84^{\circ} 36^{\prime} 10.50^{\prime \prime}$ E. The upper part of Daraudi river basin lies in Manaslu Conservation Area and it flows in Mahabharat region. The main source of river is Glacier Lake which is originated from Naradhpokhari River. The upstream boundary of the model is located approximately $5 \mathrm{~km}$ and downstream boundary is located approximately $5 \mathrm{~km}$ from the Chhepatar flood plain. The watershed spans from Manaslu, Mount Ganesh trekking route Himchuli, Larke, Bouddha Mountains and hills to plains (MoFALD, 2018). This area lies in Siranchowk Gaunpalika, Palungtar Gaunpalika and Gorkha Gaunpalika. The study area covers the two digital topo sheet maps $288415 \mathrm{C}$ and 2784 03A. The study area map is presented in (Figure 1).

\section{Methodology}

A summary of the general methodology adopted for this research is highlighted in table matrix form as below (Table 1). 


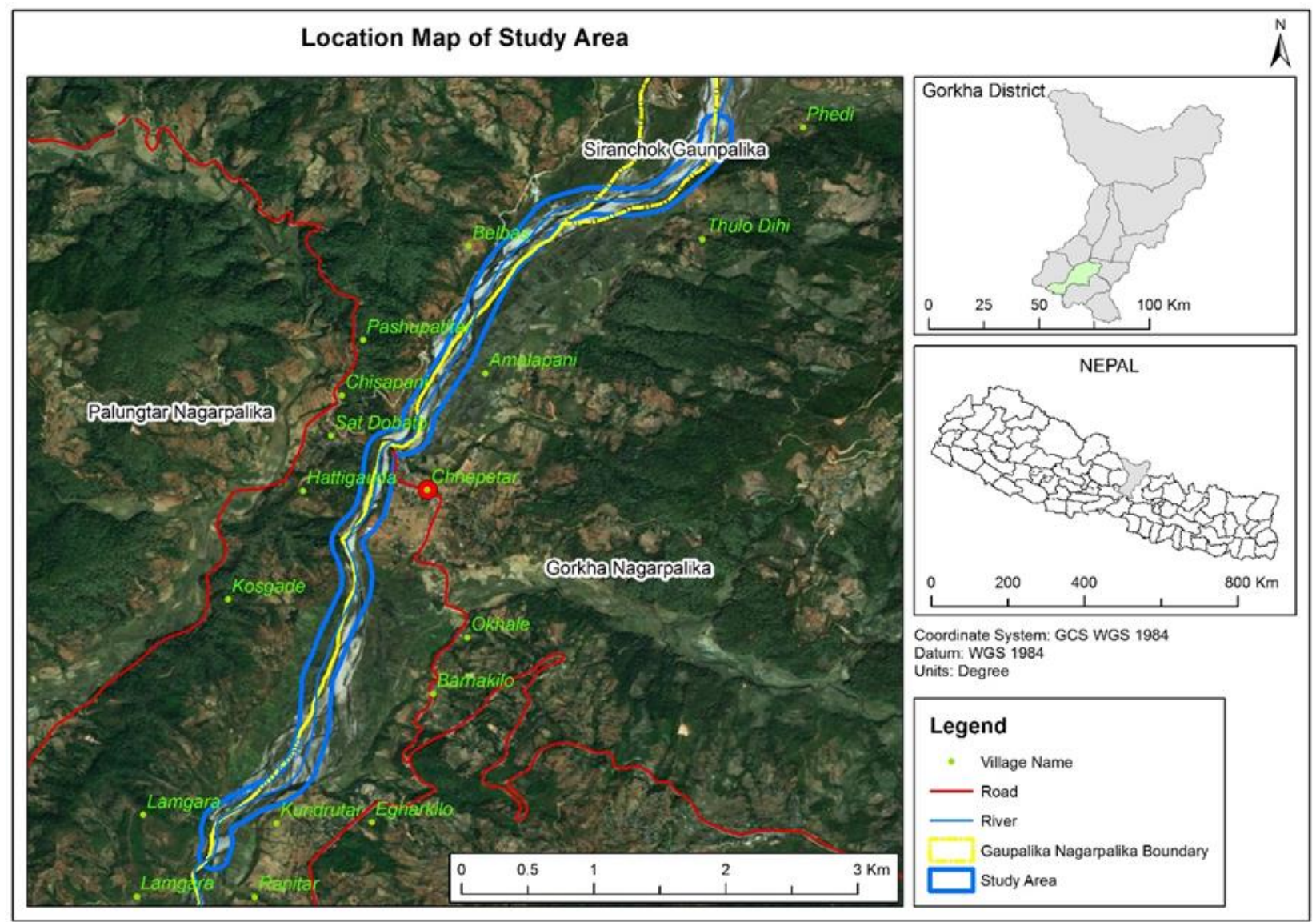

Figure 1: Study Area Map

\section{Primary and secondary information}

The data was collected from both primary and secondary sources. Primary data collection was systematic and representative using the tools like field observation, key informant interview (KII), GPS point and field verification. The field observation was done at preliminary phase. River condition and major flood control approaches were listed out through observation. GPS points were also captured during field visit. Using the predetermined checklists, seven key informants were interviewed. Local leaders, local organization members, municipality engineer, member from District Disaster Risk Response Committee, local Chairman of Red Cross Society, teachers and farmers were interviewed to obtain information and triangulate with other information. The rainfall data of 30 years was collected from the Department of Hydrology and Meteorology (DHM), Kathmandu. Rainfall data was recorded in Jagati station no.118. Likewise, the secondary data for flood mapping such as Digital Elevation Model (DEM) and other required information were collected from different secondary sources and published literature. DEM of $10 \mathrm{~m}$ resolution was used. 
Doi: https://doi.org/10.33002/nr2581.6853.02033

Table 1: Objectives and Methodologies of the Research

\begin{tabular}{|c|c|c|}
\hline Data needed & Data Collection Method & Data Analysis Tools \\
\hline $\begin{array}{l}\text { DEM of study area } \\
\text { River cross section } \\
\text { GPS coordinate } \\
\text { LULC map } \\
\text { Climatic data (rainfall) } \\
\text { History of flood event }\end{array}$ & $\begin{array}{ll}\text { - } & \text { Field visit } \\
\text { - } & \text { Google Earth } \\
\text { - } & \text { Secondary sources (DHM/DoS/LRMP) } \\
\text { - } & \text { KII checklist } \\
\text { - } & \text { Literature Review }\end{array}$ & $\begin{array}{l}\text { Arc GIS } 10.3 \\
\text { HEC-RAS 5.0.3 } \\
\text { HEC-Geo RAS } 10.3 \\
\text { Google Earth } \\
\text { GPS }\end{array}$ \\
\hline $\begin{array}{l}\text { Documentation of past } \\
\text { flood events }\end{array}$ & $\begin{array}{l}\text { Observation/field survey } \\
\text { Key Informant Survey (Engineers, } \\
\text { municipality representatives, local club, } \\
\text { women's group, DRR response committee } \\
\text { member) } \\
\text { Literature/ Reports }\end{array}$ & $\begin{array}{l}\text { MS Excel } \\
\text { MS Word }\end{array}$ \\
\hline
\end{tabular}

\section{Method and Application Procedure for Flood Mapping}

\section{Flood frequency analysis}

This study involves the different comparative method for flood flow calculation. Since the river was an ungauged river, different empirical and comparative approaches were adopted to calculate high flow discharge for different return periods $(2,5,10,50,100,200$ years), respectively.

\section{Modified Dicken's Method}

This is one of the methods widely used in Nepal and North India for the estimation of peak discharge. The peak discharge can be calculated by using the following formulae:

$\mathrm{Q}_{\mathrm{T}}=\mathrm{C}_{\mathrm{T}} \mathrm{A}^{3 / 4}$ where $\mathrm{C}_{\mathrm{T}}$ is for the return period $\mathrm{T}$, and is given by:

$\mathrm{C}_{\mathrm{T}}=2.342 \log (0.6 \mathrm{~T}) \log (1185 / \mathrm{P})+4$

With $\mathrm{P}=100\left(\mathrm{~A}_{\mathrm{S}}+6\right) / \mathrm{A}$

' $\mathrm{A}_{\mathrm{S}}$ ' is the snow-covered area out of total catchment area $\mathrm{A}$. Here $\mathrm{A}_{\mathrm{S}}=0$ and $\mathrm{P}$ is defined as $\mathrm{P}=$ 600/A.

\section{Catchment Area Method}

The catchment area ratio method is used to estimate flow in an ungauged catchment when a nearby gauged watershed is present for use as a reference. The method estimates flow at an ungauged location by multiplying the measured flow at the nearby reference gauge by the area ratio of the ungauged to gauged watershed (Archfield and Vogal, 2010). Q ungauged $=\mathrm{Q}$ gauged $\times \mathrm{A}$ ungauged *A gauged; where $Q=$ stream flow and $A=$ watershed area. A major assumption of the area ratio method is that flow is directly proportional with watershed area. That is, as watershed area increases, flow rate increases at some fixed rate per unit area. This means that the flow per unit area is the same at both the ungauged location and gauged reference location. For this study, total catchment area and Dicken's method for discharge calculation was used as a reference. 
Method of Water and Energy Commission Secretariat, Department of Hydrology and Meteorology (WECS/DHM)

To determine the flood flow of any river, the equation developed by WECS and DHM (Sharma et $a l ., 2003$ ) was adopted in this study. The equation gives the flood flow for certain years of flood with the catchmnet area of " $\mathrm{A}$ " $\mathrm{km}^{2}$ lying below the elevation of $3000 \mathrm{~m}$.

For instance, the flood flow for 2 years and 100 years of flood is calculated as mentioned below:

$\mathrm{Q} 2=2.29(\mathrm{~A}<3 \mathrm{~K}) 0.86$

$\mathrm{Q} 100=20.7(\mathrm{~A}<3 \mathrm{~K}) 0.72$

Where, $\mathrm{Q}$ is the flood discharge in $\mathrm{m}^{3} / \mathrm{sec}$ and $\mathrm{A}$ is basin area in $\mathrm{km}^{2}$.

Subscript 2 and 100 indicate 2-year and 100-year flood, respectively.

Similarly, subscript 3K indicates area below $3000 \mathrm{~m}$ altitude.

Further, following relationship will be used to estimate floods at other return periods.

$\mathrm{Q}_{\mathrm{T}}=\exp (\ln \mathrm{Q} 2+\mathrm{s} \sigma)$,

Where, $\sigma=\ln (\mathrm{Q} 100 / \mathrm{Q} 2) / 2.326$

$\mathrm{s}=$ standard normal variant for particular return period $(\mathrm{T})$ given in table below (Table 2).

\section{Table 2: Values of standard normal variate /s used in WECS/ DHM}

\begin{tabular}{lll}
\hline S. No. & Return period $(\mathrm{T})$ in years & Standard normal variate $(\mathrm{s})$ \\
1 & 2 & 0 \\
2 & 5 & 0.842 \\
3 & 10 & 1.282 \\
4 & 20 & 1.645 \\
5 & 50 & 2.054 \\
6 & 100 & 2.326 \\
7 & 200 & 2.576 \\
8 & 500 & 2.878 \\
9 & 1000 & 3.09 \\
\hline
\end{tabular}

\section{Methodological Flow Chart for HEC-RAS Mapping}

The approach used for floodplain analysis and risk assessment using one-dimensional model, HEC-RAS, ArcGIS and HEC-GeoRAS is depicted in the flow chart below (Figure 2).

\section{Flood Simulation}

PreRAS, postRAS and GeoRAS menus of HEC-GeoRAS extension in ArcGIS environment were used to create data sets, making import file for model simulation in HEC-RAS. 


\section{Pre Geo-RAS Application}

The pre-RAS menu option was used for creating required data sets for creating import file to HEC-RAS. Stream centerline, main channel banks (left and right), flow paths, and cross sections were created. 3D layer of stream centerline and cross section was also created. Land use Manning table containing land use type of the study area and Manning roughness coefficient, ' $n$ ' value, was created from Geo-RAS menu for different land uses. Thus, Manning's ' $n$ ' value was assigned as taken from HEC-RAS hydraulic reference manual (2016) for different land use types within the study area. Thus, after creating and editing required themes, RAS-GIS import file was created.

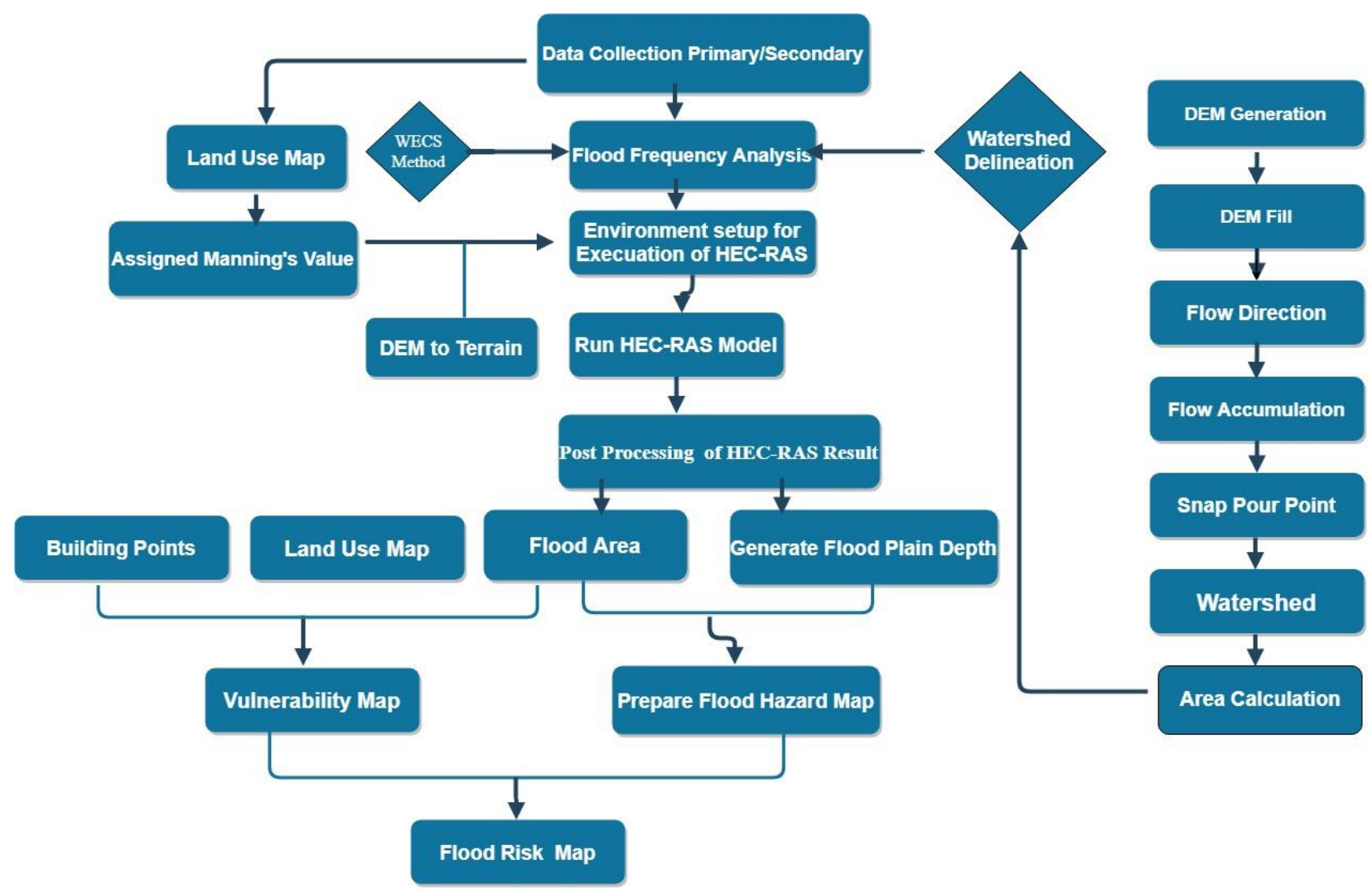

Figure 2: Flow Chart for flood mapping

\section{HEC-RAS Application}

This is the major part of the model where simulation is done. The import file created by HEC-GeoRAS was imported in Geometric Data Editor interface within HEC-RAS. All the required modification and editing was done at this stage. The flood discharge for different return periods was entered in steady flow data. Reach boundary conditions were also entered in this window. Then, water surface profiles were calculated in steady flow analysis window. After the simulation, RAS-GIS export file was created. Water 
surface profiles were computed from one cross section to the next by solving the energy equations with an iterative procedure. The flow data were entered in the steady flow data editor for five return periods as 2-year, 5-year, 10-year, 50-year, 100-year and 200-year. Thereafter, water surface profiles were computed. The result was exported creating the RAS-GIS export file.

Table 3: Manning's Roughness Coefficient for Different Land use

\begin{tabular}{|l|l|}
\hline Land use type & Manning's n Value \\
\hline Barren Land & 0.030 \\
\hline Bush & 0.050 \\
\hline Cultivation Area & 0.035 \\
\hline Cutting Area & 0.040 \\
\hline Forest & 0.100 \\
\hline Grass land & 0.035 \\
\hline Orchard & 0.055 \\
\hline River & 0.040 \\
\hline Sand & 0.030 \\
\hline
\end{tabular}

A value of $n=0.03$ was taken as the Manning's roughness parameters for the river channel and $n=0.04$ for the floodplain area. These values were adopted on the basis of previous modelling experience in the Terai region of Nepal carried out by the Department of Hydrology.

\section{Post-Processing of HEC-RAS Results and Floodplain Mapping}

After the development of a GIS import file from HEC-RAS, post-processing steps start. Different steps involved in this process are: After completing "Theme Setup" and "Read RAS GIS Export File", this will read the results from the export file and create initial data sets. The stream network, cross section data, bank station data and bounding polygon data will be read, and shape files will automatically be generated. Based on water surface elevations of the cross-sectional cut lines and bounding polygon theme, water surface TIN was generated for each water surface profiles.

\section{Flood Risk Assessment}

The methodology adopted for flood risk assessment follows the approach developed by Gilard (1996). Flood risk is defined as the product of flood hazard and vulnerability to flooding.

Flood Risk = Flood Hazard x Vulnerability

The results of these two analyses are combined for the flood risk assessment. This risk assessment process is automated by the use of customized graphical user interface in the ArcGIS.

\section{Flood Hazard Analysis, Gilard (1996)}

Flood hazard assessment is based on the flood water depth indicated by prepared flood map of Daraudi watershed. For this, we ranked the hazard levels in terms of water depth and these levels are determined by reclassifying the flood grid water depth bounding cells. We categorized three 
hazard levels based on water depth such as low (0-1 m), moderate (1-2 m) and significant (2-3 m) and very high $(>3 \mathrm{~m})$ area bounded by each level is calculated and flood hazard map was prepared.

\section{Flood Vulnerability Analysis, Gilard (1996)}

The flood vulnerability depends on the land use characteristics of the area under influence of flood and their potential for damage. So, for the vulnerability assessment, vulnerability maps are prepared, for which the land use themes of the floodplains are clipped with the flood area polygons for each of the flood events being modeled. The result is achieved in terms of the presence or the absence of flooding of a particular return period as a binary model. The land use areas under the influence of each of flooding events are reclassified for the calculation of the total vulnerable areas.

\section{Flood Risk Analysis, Gilard (1996)}

The combined results of both the vulnerability analysis and the hazard analysis gives the flood risk analysis. It relates the land use vulnerability classes and the flood depth hazard classes in a particular area. The flood depth grids are overlaid with the land use map to prepare flood risk map. Furthermore, the flood depth polygons prepared during the hazard analysis is intersected with the land use vulnerability polygons.

\section{Results}

\section{Flood Frequency Analysis}

In this study, the flood flow for various return periods was calculated. The maximum instantaneous flood discharge for 2, 5, 10, 20, 50, 100, 200 years return period, respectively, using various estimation method is presented in (Table 4).

Table 4: Flood Frequency Table

\begin{tabular}{lccccccccc}
\hline Discharge $\left(\mathrm{m}^{3} / \mathrm{sec}\right)$ & at various return periods & & & & & & \\
\hline Return Period & 2 & 5 & 10 & 20 & 50 & 100 & 200 & 500 & 1000 \\
$\begin{array}{l}\text { Modified Dickens } \\
\text { Method }\end{array}$ & 659 & 747 & 814 & 880 & 968 & 1034.9 & 1101.5 & 1189.5 & 1256 \\
$\begin{array}{l}\text { Catchment Area } \\
\begin{array}{l}\text { Method } \\
\text { WECS/DHM }\end{array}\end{array}$ & 445.1 & 720.7 & 929 & 1138 & 1413 & 1621.8 & & & \\
\hline
\end{tabular}

\section{Catchment Area Calculation}

DEM was clipped by watershed boundary to fix study area boundary. The vertical profile of the watershed ranges from $306 \mathrm{~m}$ to 6,066 $\mathrm{m}$ elevation. The elevation of study area is presented (Figure 3). Total catchment area of Daraudi River Basin was calculated. The total catchment area occupied by Daraudi River was about $471.26 \mathrm{~km}^{2}$. 


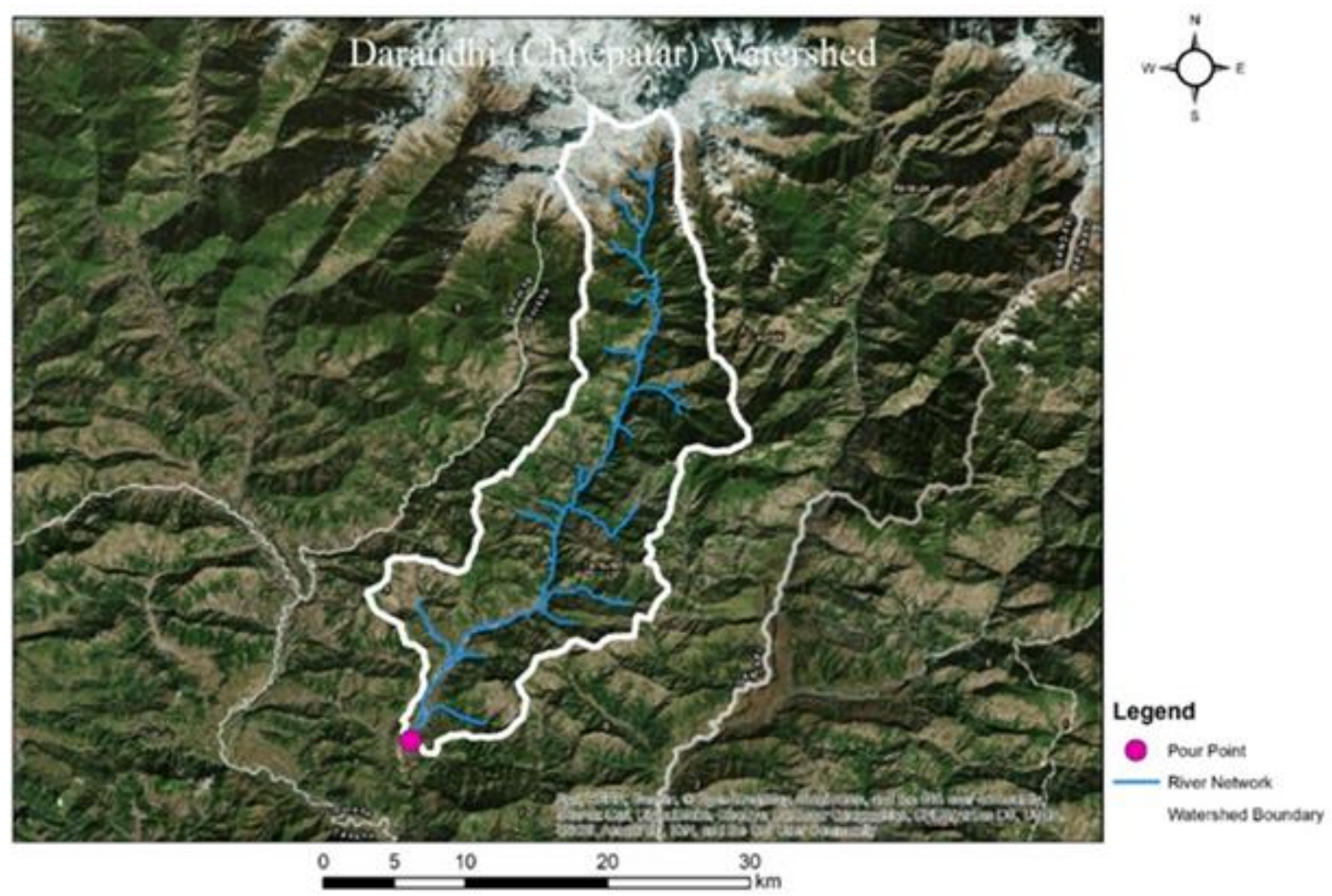

Figure 3: Watershed Boundary/River Network

\section{Land Used/Land Cover Analysis}

The land use/land cover map was collected from LRMP project 2015 of Department of Survey Nepal (DoS). The land used and land cover map was prepared (Figure 4). The different land class obtained from the land use map is presented (Table 5).

Table 5: Land use type

\begin{tabular}{lcc}
\hline Land use & Area in ha & Percentage \% \\
\hline Agriculture- Level Terrace & 15183.4 & 32.2 \\
Agriculture- Valley, Tar & 1116.4 & 2.4 \\
Agriculture- Sloping Terrace & 249.0 & 0.5 \\
Residential & 572.3 & 1.2 \\
Forest & 22403.8 & 47.6 \\
Sand/Gravel/Boulders & 815.6 & 1.7 \\
Shrub land /Grassland & 3725.4 & 7.9 \\
Snow/Glacier & 3026.6 & 6.4 \\
\hline Total & 47092.5 & 100.0 \\
\hline
\end{tabular}


Analysis of the land use map (Figure 4) showed that the forest land use class had the highest value of $47.77 \%$ followed by agriculture $35 \%$ and bushes/grassland $7.91 \%$, snow/glacier $6.43 \%$, others (sand gravel, residential water bodies) occupying $3 \%$ of the total area.

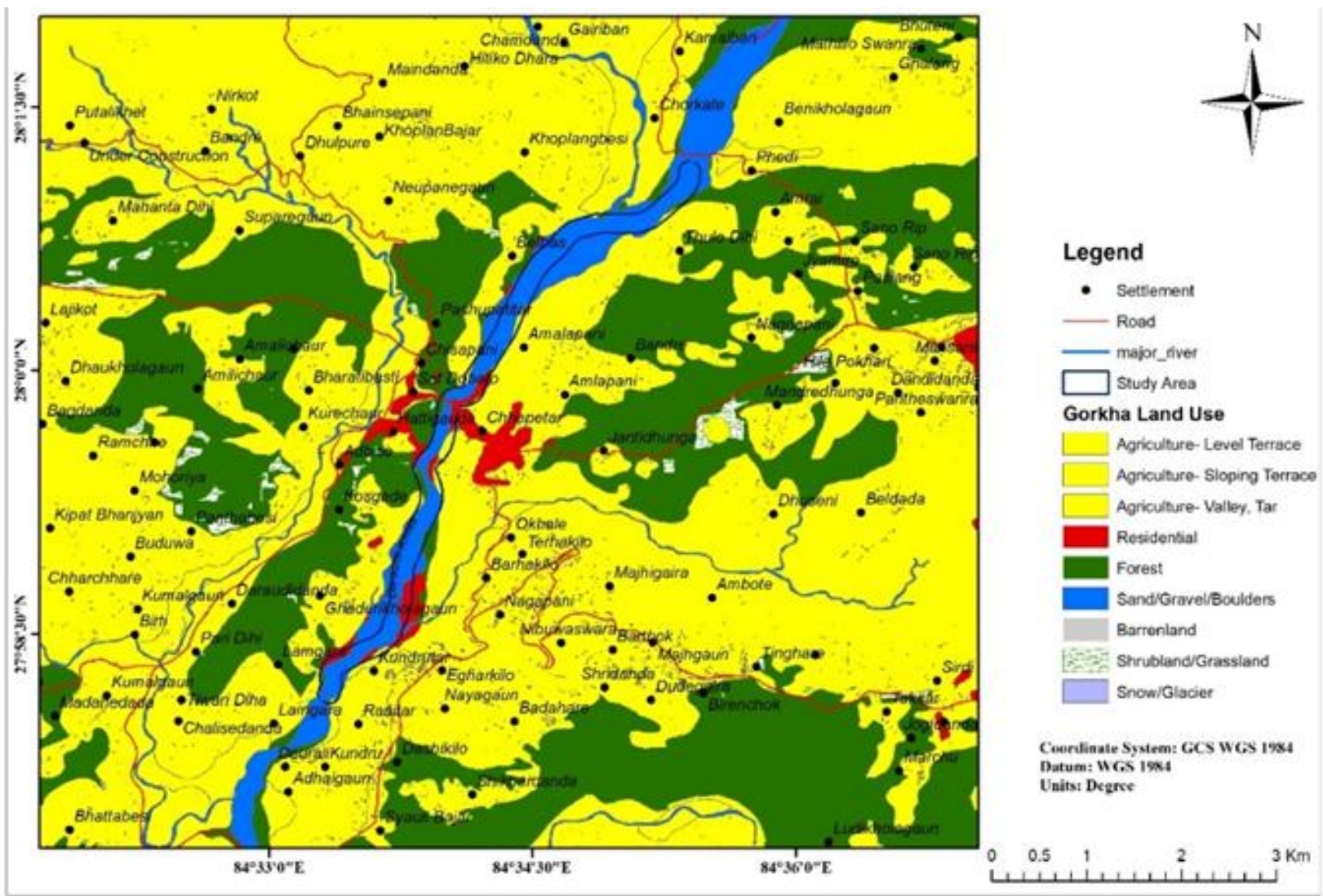

Figure 4: Land Cover Map

\section{Flood Hazard Map}

The flood inundation maps (Figure 5) were prepared and inundated area was calculated. The analysis of flood inundation map indicates that considerable increase in flood inundation with increasing discharge of flood was shown from 2 years to 200 years return period. 

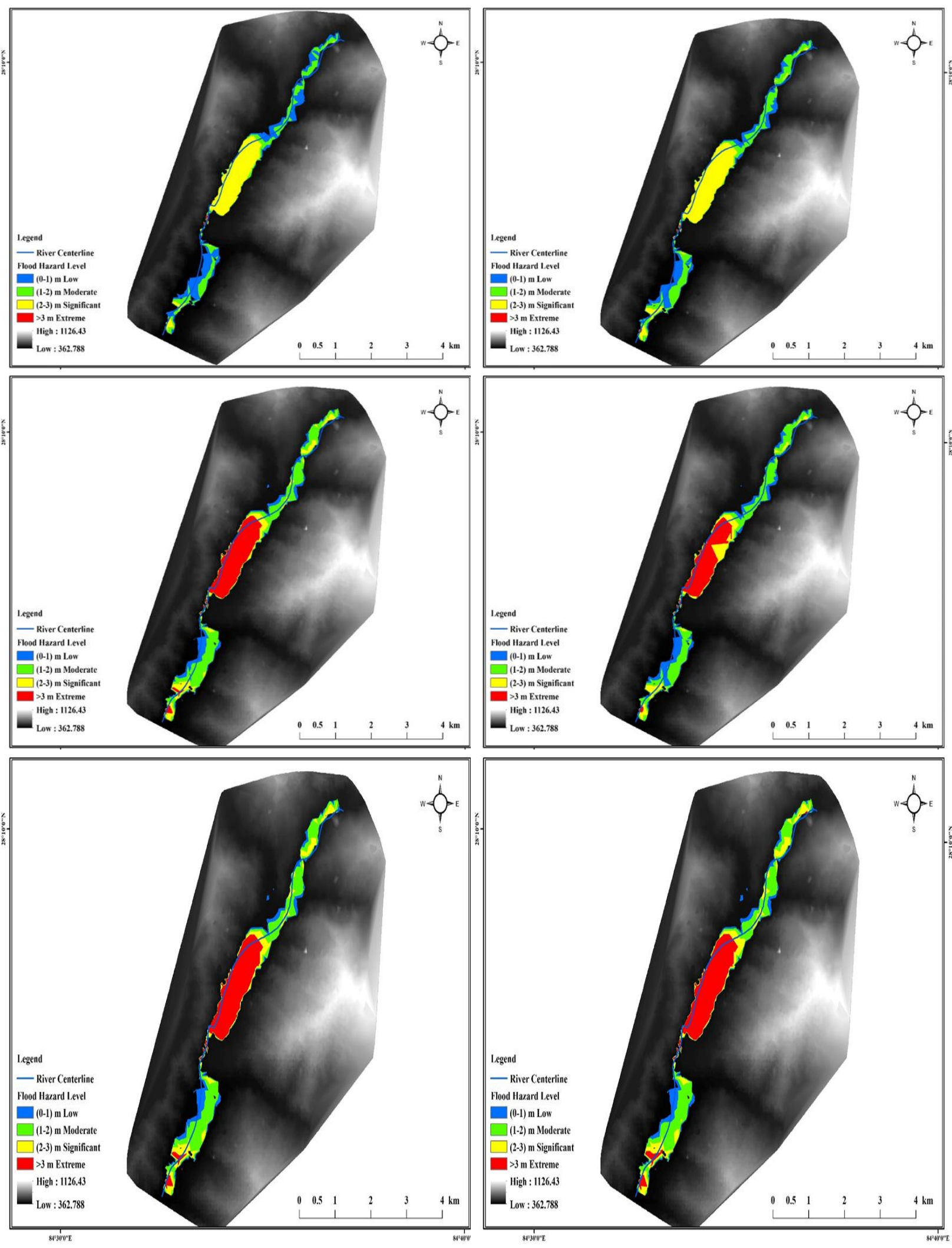

Figure 5: Flood Hazard Map for Various Return Period 
The findings shown in figure 6 shows that total inundation area is progressively increasing with increasing return periods.

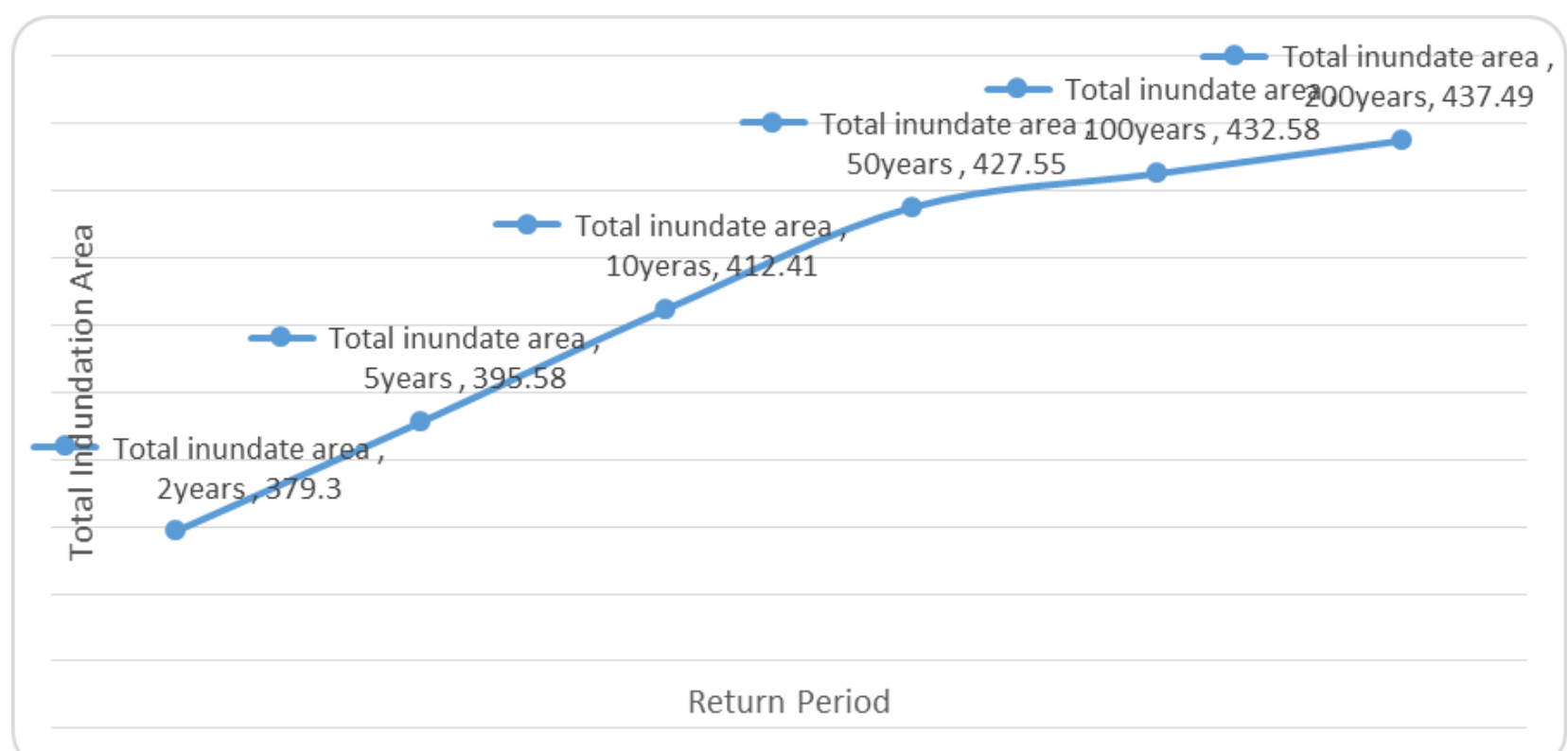

Figure 6: Inundation Area Curve

Flood Vulnerability Analysis

Flood vulnerability was analyzed using the vulnerability graph (Figure 7) for the flood areas. This gives the vulnerability aspect of the flood risk in the particular area in terms of the presence or the absence of flooding of a particular return period as a binary model (Figure 7 and 8).

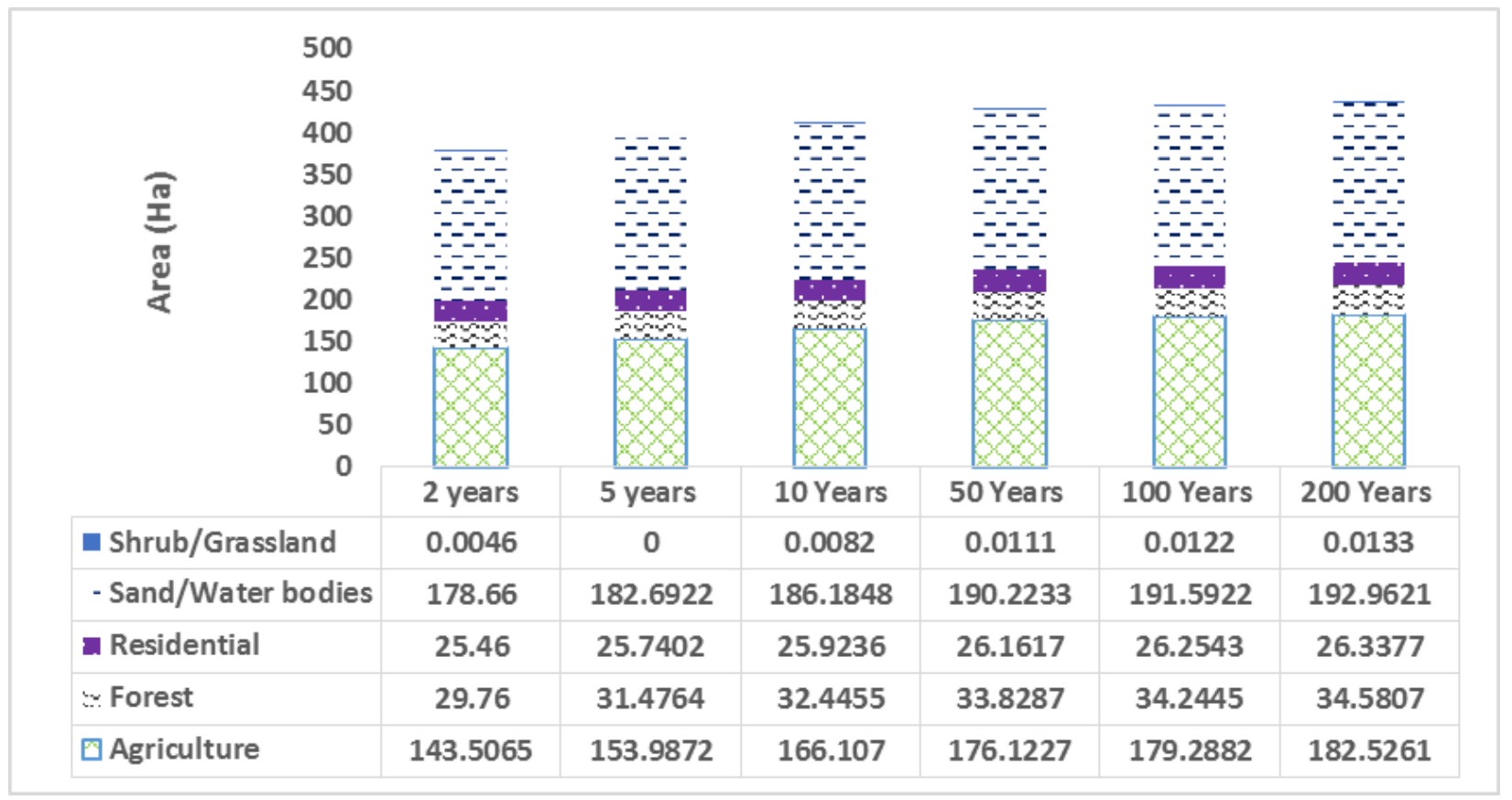

Figure 7: Vulnerability Classification of Land use for every Return Period

Pratibha Banstola, Bidhan Sapkota 
Doi: https://doi.org/10.33002/nr2581.6853.02033

From the figure 7 it is found that there is slight change in settlement due to flood. However, settlement is the important sector with reference to vulnerability. In each successive return period, the areas of residential land inundation are 25.76 ha, 25.7402 ha, 25.92 ha, 26.16 ha, 26.25 ha, 26.33 ha from 2 years to 200 years, respectively (Figure 8).

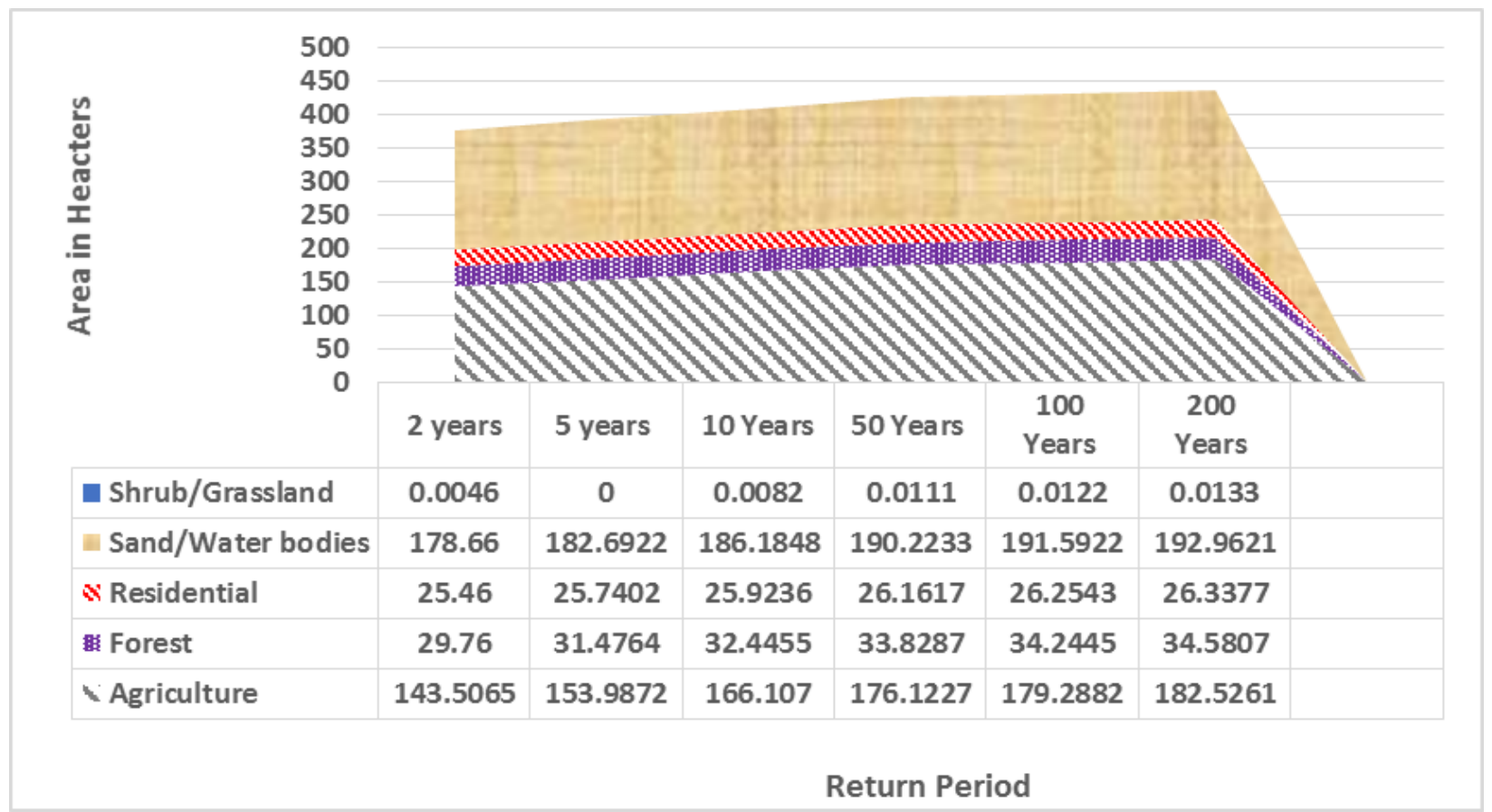

Figure 8: Vulnerability Classification of Important land

In this study, it has been found (Figure 9) that settlement/residential area inundated for 2 years flood is 25.46 ha; similarly, the inundated area slightly increases over successive return periods and the total inundated area for a 200 years is 26.34 ha.

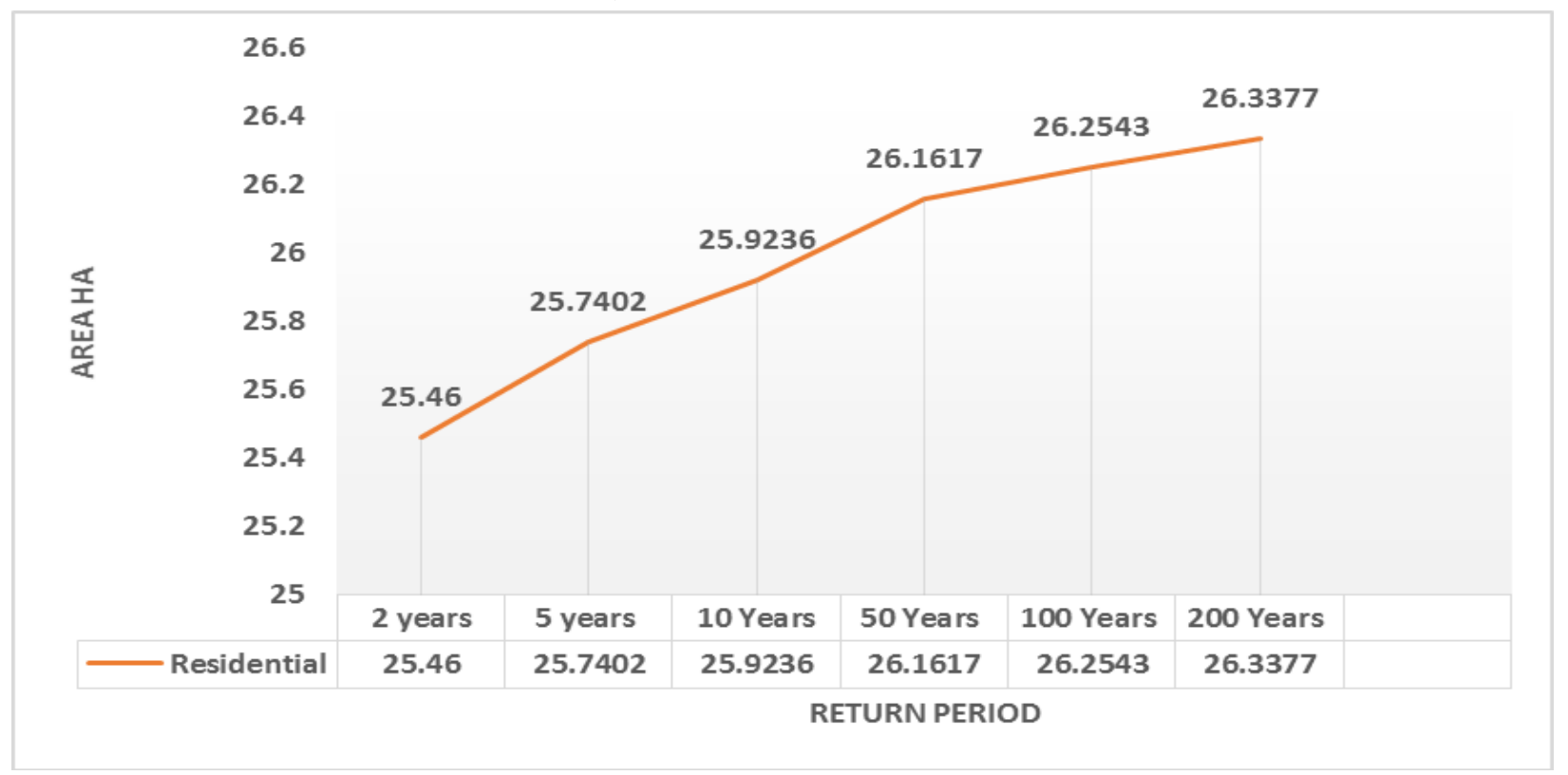

Figure 9: Change in Inundated area within Settlement Area 
Doi: https://doi.org/10.33002/nr2581.6853.02033

\section{Flood Risk Analysis}

The flood risk analysis is based on combined result of vulnerability and hazard assessment. The analysis of the flood inundation map with the class value allocated for the study indicated a gradual increase in the area extreme hazard (2-3 m range) while there was a positive increase in all other hazard class (Figure 10).

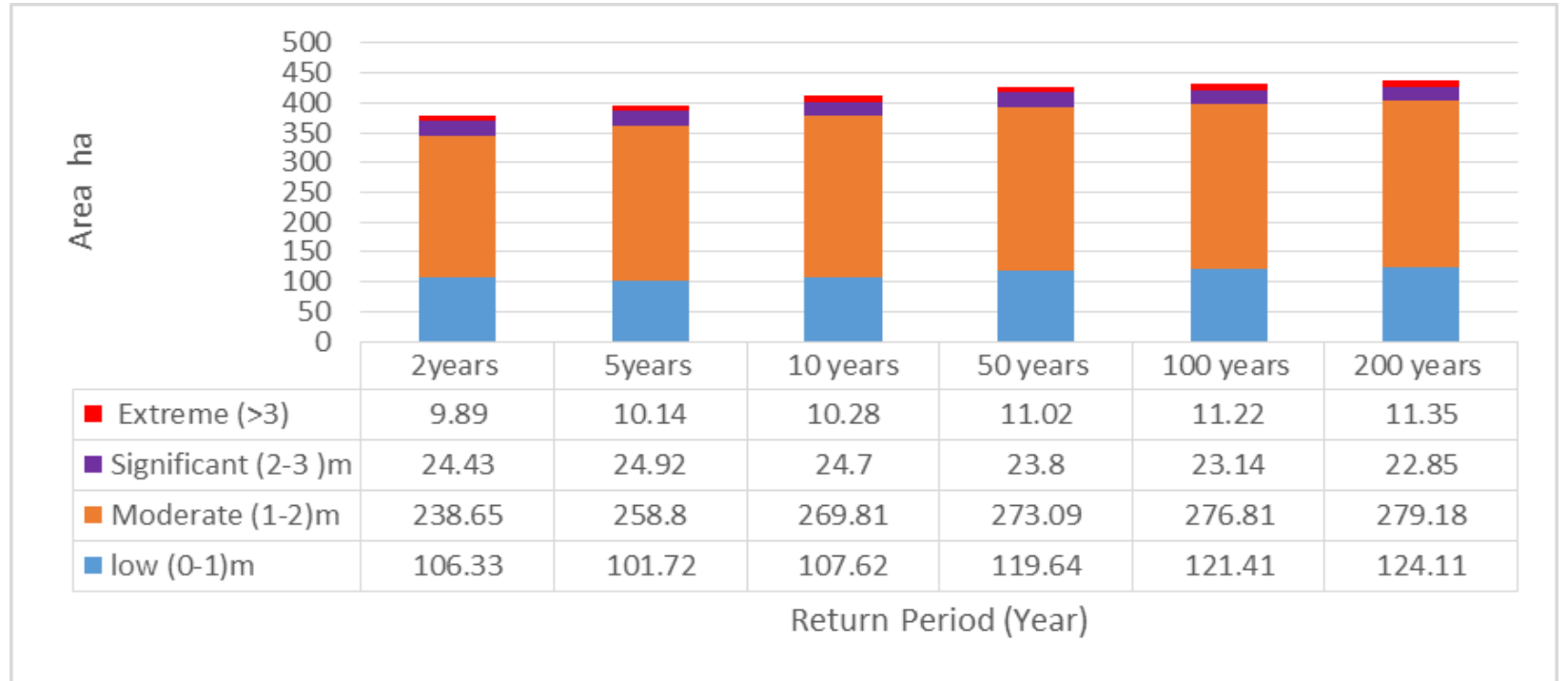

Figure 10: Depth of Inundation and the Respective Inundated Area

The analysis of the relationship between the flood hazard level and settlement area (Figure 11) indicated a gradual increase in all hazard class in all return periods. The settlement area under low hazard class $(<1 \mathrm{~m})$ is $1.3,1.03,0.91,0.86,0.80,0.84$ ha for return periods 2 to 200 years and that of moderate hazard class, $(2-3 \mathrm{~m})$ is $20,20.41,20.67,20.91,21.09,21.12$ ha for successive return period. The data revels that moderate hazard class have more value than other classes. Likewise, in extreme class (>3 m) settlement area is $0.51,0.63,0.71,0.96,1.07,1.16$ ha.

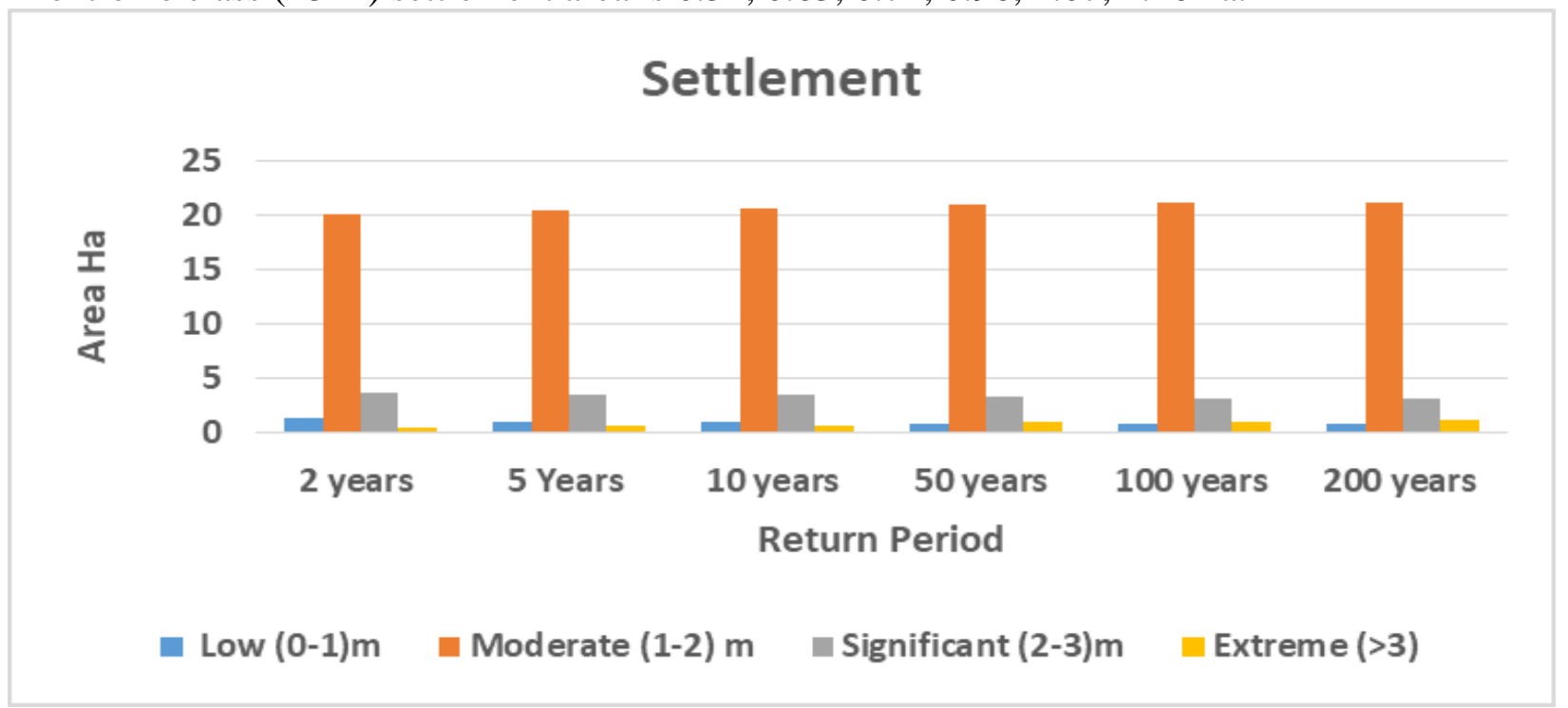

Figure 11: Risk Classification of Settlement Land Use Type

Pratibha Banstola, Bidhan Sapkota 
Similarly, agricultural area under low hazard class (Figure 12) indicated that $(<1 \mathrm{~m})$ is $50.59,51.92$, $59.22,67.62,69.40,71.76$ ha for return periods 2 to 200 years. It shows that in moderate class hazard, there is maximum value which shows that more area is in risk at moderate class and that of extreme class $(2-3 \mathrm{~m})$ is $3.6,3.6,3.6,3.28,3.15,3.06$ ha.

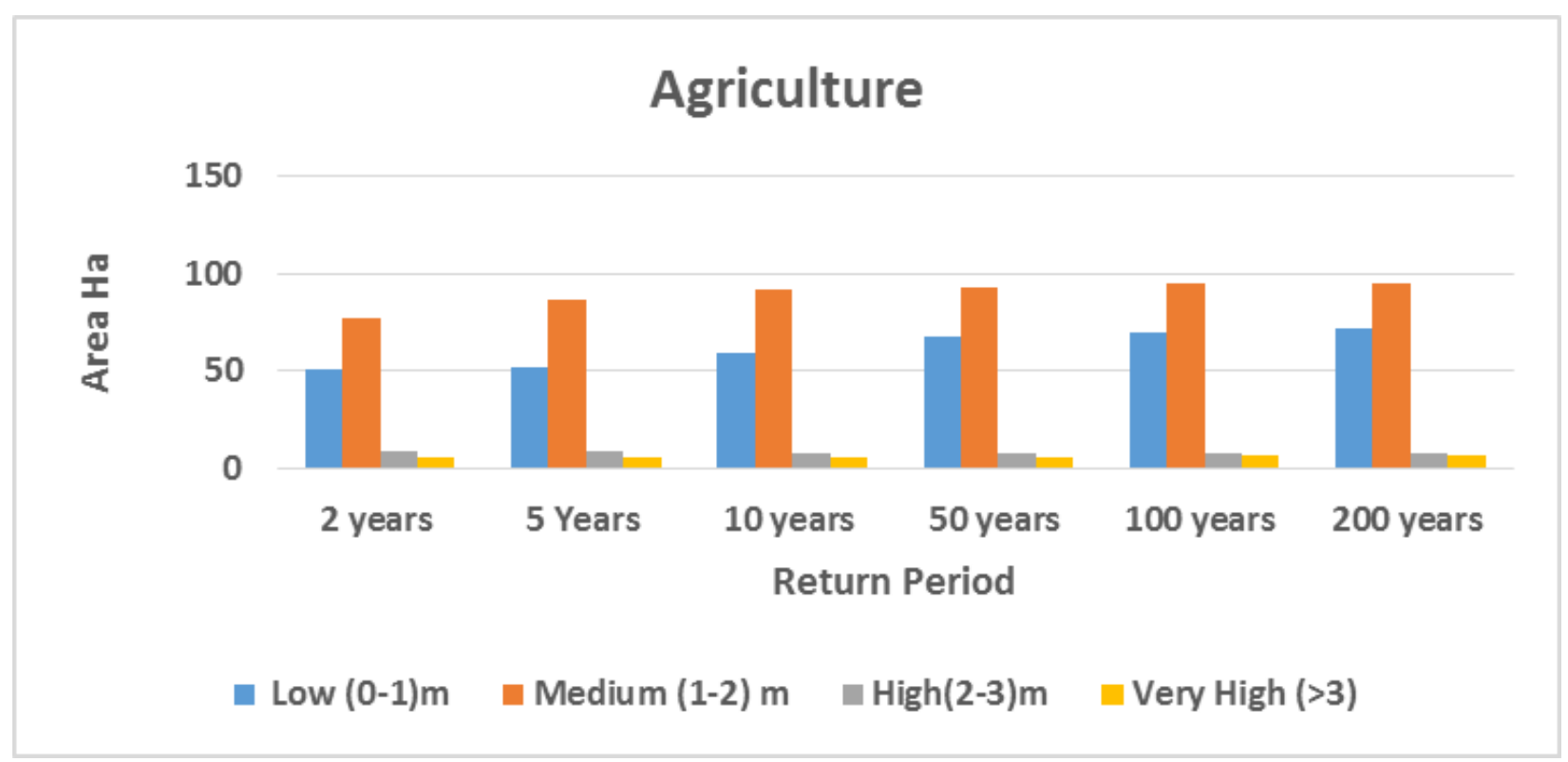

Figure 12: Risk classification of Agriculture Land use Type

The figure 13 shows the relationship between forest land and flood hazard. In forest sector, there is also gradual increase in every return period except in extreme hazard.

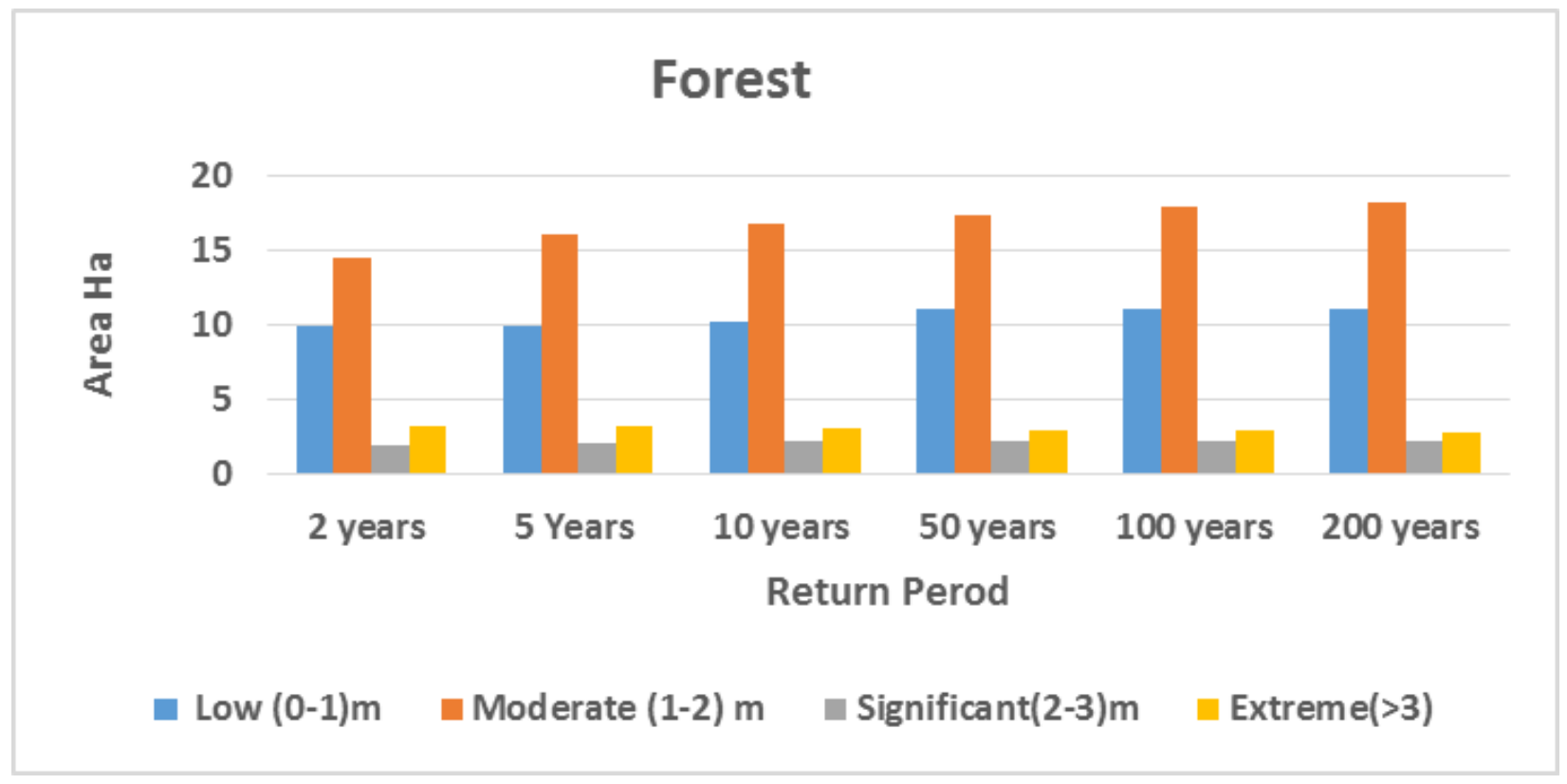

Figure 13: Risk classification of Forest Land use Type 
Doi: https://doi.org/10.33002/nr2581.6853.02033

\section{Past Flood Events History}

Past flood events in the study area has been identified and verified with rainfall amount and flood date of such events from primary and secondary survey is presented in table 6 .

Table 6: Flood verification table with rainfall

\begin{tabular}{|l|l|l|l|l|}
\hline S.No. & Flood events year $(A D)$ & $\begin{array}{l}\text { Monthly Max. } \\
\text { rainfall amount } \\
(\mathrm{mm}) \text { with flood }\end{array}$ & $\begin{array}{l}\text { Previous month } \\
\text { rainfall }(\mathrm{mm})\end{array}$ & $\begin{array}{l}\text { Next month } \\
\text { rainfall }(\mathrm{mm}\end{array}$ \\
\hline 1 & 1949 July & - & & \\
\hline 2 & 1954 July & -- & & \\
\hline 3 & 1961 October & - & & \\
\hline 4 & 2003 July & 457.8 July & 218.5 & 333.5 \\
\hline 5 & 2010 July & 545.8 & 240.4 & 353.4 \\
\hline 6 & 2011 July & 466.3 July & 270.7 & 344.7 \\
\hline 7 & 2012 June/July & 398.6 & 375.8 & 198.3 \\
\hline
\end{tabular}

\section{Rainfall Data Analysis}

The rainfall data of 30 years (1988 AD to 2017 AD) recorded at Jagati station was collected from DHM (2018). The total annual rainfall was calculated, and the trend shows that total annual rainfall increased at the rate of $42.28 \mathrm{~mm} /$ year (Figure 14 and 15). A 24 hours period maximum rainfall was also analyzed. Trend shows that rainfall increased at the rate of $10.98 \mathrm{~mm} /$ year.

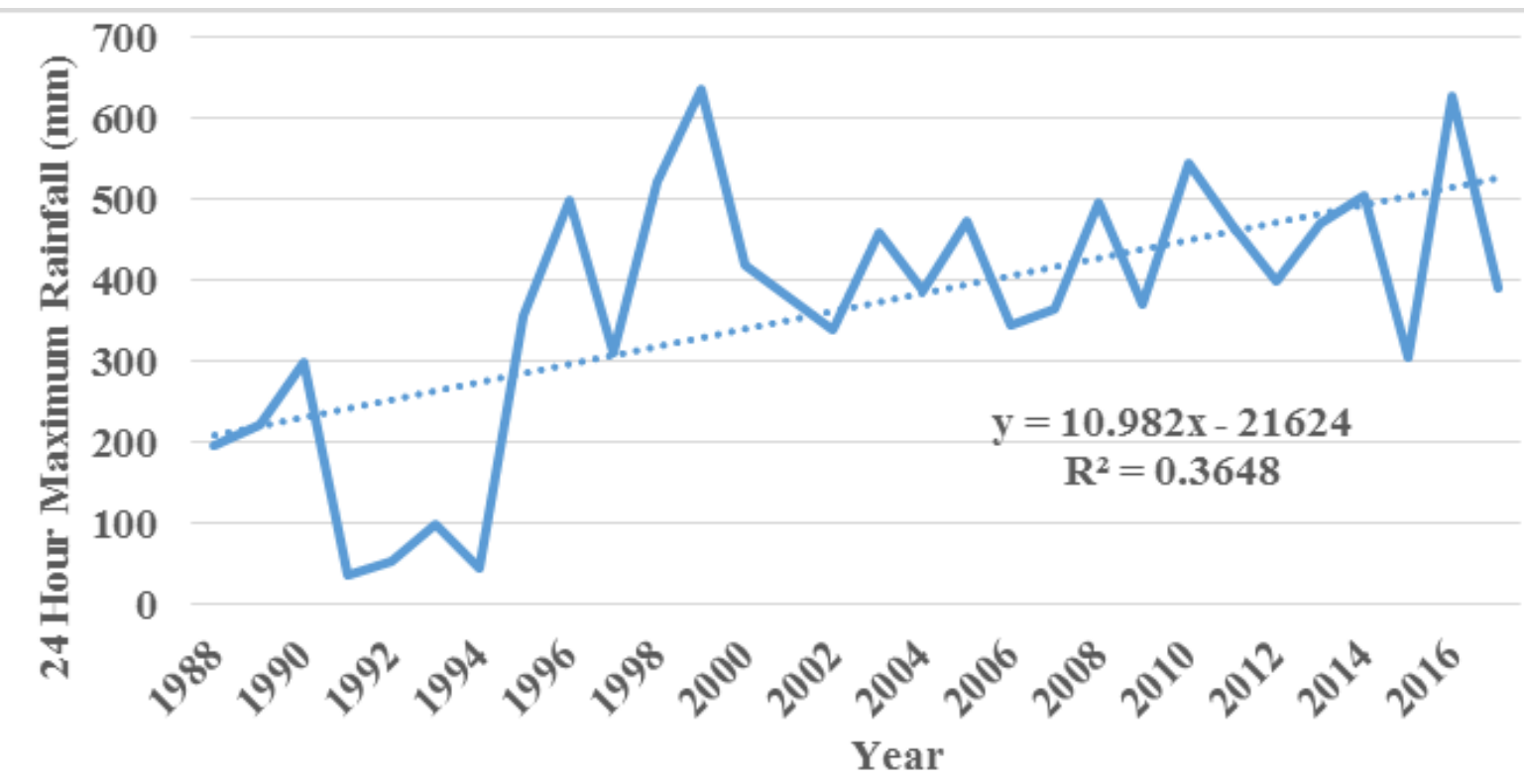

Figure 14

Pratibha Banstola, Bidhan Sapkota 


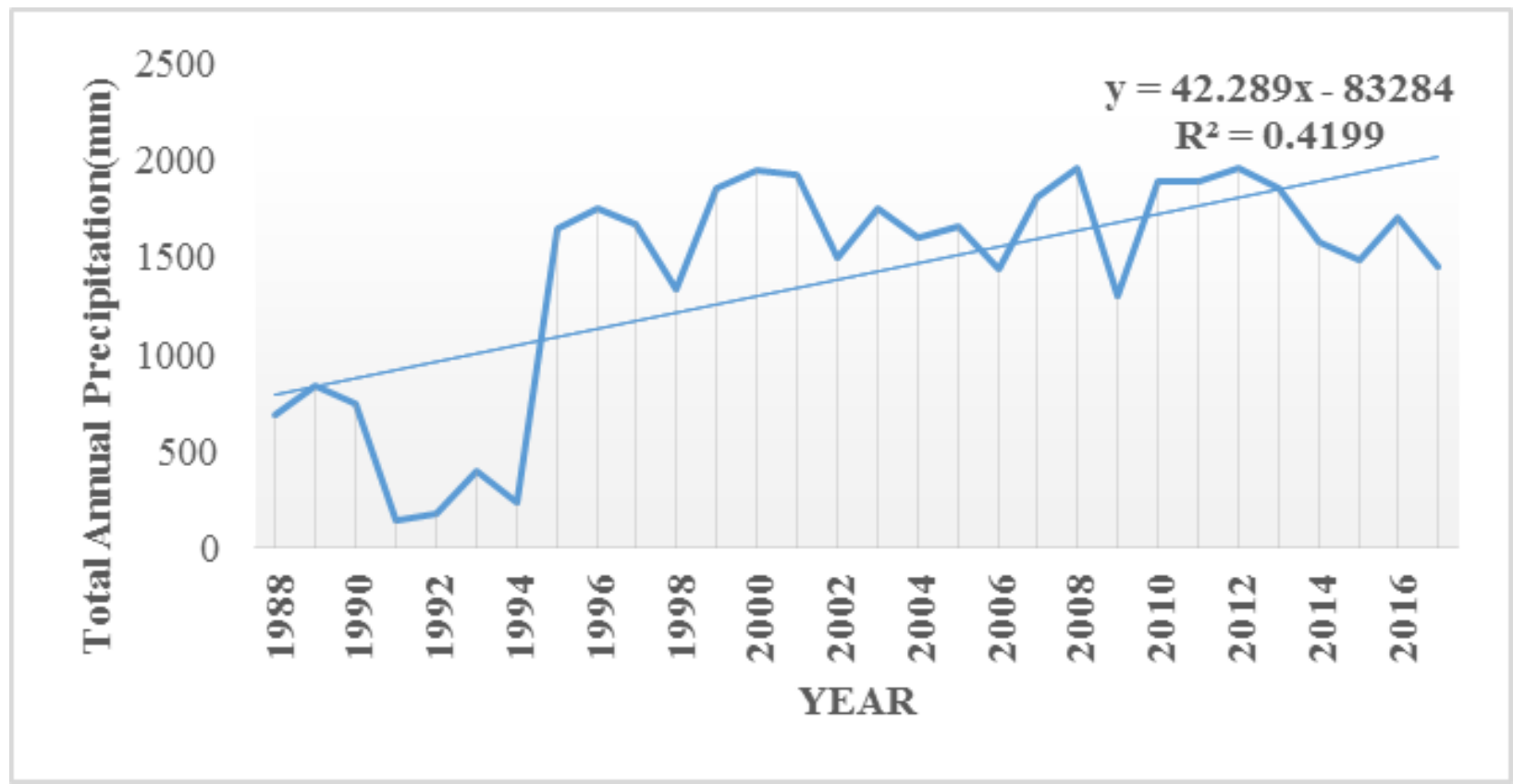

Figure 15

\section{Discussion}

The flood frequency and peak discharge of different return periods were calculated using the WECS/DHM method. The peak flood discharge of $1524.288 \mathrm{~m}^{3} / \mathrm{s}, 1344 \mathrm{~m}^{3} / \mathrm{s}, 1173.27$ $\mathrm{m}^{3} / \mathrm{s}, 61.05 \mathrm{~m}^{3} / \mathrm{s}, 796.69 \mathrm{~m}^{3} / \mathrm{s}$ and $638 \mathrm{~m}^{3} / \mathrm{s}$ were found for $200,100,50,20,10$ and 5 years of different return periods, respectively. Flood inundation maps indicate that there is a considerable increase in inundation area with an increase in the amount of peak discharge found in successive return periods. The flood hazards and agricultural area show that the areas in all hazard classes show a gradual increase in value in each successive return period. The agricultural area under low hazard class $(<1 \mathrm{~m})$ is $50.59,51.92,59.22,67.62,69.40,71.76$ ha for return periods 2 to 200 years and in medium class hazard, there are higher values which show that more area is at risk at medium class. Using the same method for study in Kankai River, the authors found that total of $59.3 \mathrm{sq}$. km and $59.8 \mathrm{sq}$. $\mathrm{km}$ of the study area will be under the impact of flooding in a 25 year-return period floods and 50 year-return period floods, respectively. Agriculture system is in more vulnerable position, and, according to level of hazard, high hazard area will increase, and more settlement will be under the high hazard zone. The hazard prone area will considerably increase from 25 yearreturn period floods to 50 year-return period floods. Vulnerability assessment regarding flooding and climate change depicts that peoples' livelihood are worsening each year which has similar inference as that of the study findings of Karki et al. (2011). Likewise, in settlement areas, there is slight change in settlement due to inundation. However, settlement is the important sector with reference to vulnerability. In each successive return period, the area of settlement inundation is seen to be increasing. Flood simulation was conducted for the computed discharge values using HEC-RAS and ArcGIS. HEC Geo-RAS extension facilitated the exchange of data between Arc GIS and HEC-RAS. The occurrence of floods in mountainous regions are now becoming more common related to the past, and in the future too; it seems more frequent flood events will be seen 
due to global warming (Ali et al., 2016). Measures like watershed management, bioengineering and alternating the economic activities of upstream, downstream and surrounding communities to stop the land degradation and sediment production and proper communication between them as a means of early warning system would be highly effective to reduce flood risk and minimize its effects to a great extent. River training and check dams for erosion control in the midstream, and embankment construction, shelter houses, safe escape route, water level monitoring systems and formation of information centres would be more contributing. The adaptation practices such as river bank plantation, integrated watershed management specifically drainage management, irrigation channel with specific bioengineering techniques were the key and existing potential adaptation cases in Gandaki river basin of western Nepal (Regmi and Pandit, 2016).

\section{Conclusions}

One dimensional steady flow model HEC-RAS was used for the flood hazard analysis of the floodplain. ArcGIS and HEC-Geo-RAS were used for the preparation of flood hazard maps. Flood hazard maps for floods with probable return period of 2 years, 50 years, 100 years, and 200 years were prepared. The flood risk analysis was done by crossing of vulnerability classes with flood depth hazard class. Low hazard $(<1 \mathrm{~m})$, moderate hazard $(1-2 \mathrm{~m})$, significant $(2-3 \mathrm{~m})$ and extreme $(>3 \mathrm{~m})$ were the four classes of flood depth analysis used in this research. Certain inferences are drawn as summed up below:

i. The analysis of the flood hazard map indicated a considerable increase in inundated area with an increase in the amount of peak discharge found in successive return period.

ii. The total inundated area was found to be 379.3, 395.58, 412, 427, 432 and 437 ha for 2, 5, $10,50,100$ and 200 years return period, respectively, including all defined hazard levels.

iii. The agricultural area under low hazard class $(<1 \mathrm{~m})$ is 50.59, 51.92, 59.22, 67.62, 69.40, 71.76 ha for return periods 2 to 200 years and it shows that in moderate hazard class, there is maximum value which shows that more area is in risk at moderate class. The same of extreme hazard class $(2-3 \mathrm{~m})$ is $3.6,3.6,3.6,3.28,3.15,3.06$ ha.

iv. The settlement area under low hazard class $(<1 \mathrm{~m})$ is $1.3,1.03,0.91,0.86,0.80,0.84$ ha for return periods 2 to 200 years and that of significant hazard class $(2-3 \mathrm{~m})$ is $20,20.41,20.67$, $20.91,21.09,21.12$ ha for successive return periods. The data reveals of medium class hazard have more value than other classes. Likewise, in extreme hazard class $(>3 \mathrm{~m})$, settlement area is $0.51,0.63,0.71,0.96,1.07,1.16$ ha.

v. The maximum 24 hour monthly rainfall is increasing at the rate of $10.66 \mathrm{~mm} / \mathrm{year}$ up to the year 2017. All identified flood events correspond to the maximum rainfall in that year. However, rainfall amount per day or even per hour, temperature change, land use, development activities, etc. are also to be considered for better results.

vi. Flood management should be linked through cause and effect analysis approach. The watershed management and bioengineering stop the land degradation and sediment production and effective communication between the major stakeholders as a means of early warning system would be highly effective not only to reduce flood risk and to minimize the risk of flood to greater extent but also would promote and sustain diversified and sustainable livelihoods. 
Doi: https://doi.org/10.33002/nr2581.6853.02033

\section{Recommendations}

Owing to limited availability of data was the primary constraint of the study; hence, the results presented in this research reflects the outcome based on the availability of data as they represent. Therefore, the following recommendations are made for further studies in the future.

i. Topographical data used for the preparation of the map determines the accuracy of a flood hazard map. Thus, for the modeling of overbank flow, high resolution topographic data should be used so that proper representation of floodplain topography can be made.

ii. Use of new technologies should be encouraged which improves the quality of the digital terrain representations and can be used for further study.

iii. Gauge station should be installed to record and acquire all hydrological data for further study.

iv. Turbulent flows are unsteady and natural river course are turbulent, hence unsteady flow simulation should also be considered for flood hazard mapping.

\section{Acknowledgements}

I would like to acknowledge to my supervisor, Mr. Prem Krishna, SchEMS College and Faculty. My special thanks to WWF for providing grants and Mr. Utsav Bhattarai for his valuable inputs and suggestions. The cooperation of the people of Chhepatar, Gorkha with the required information to produce the results of this research study deserves a special mention.

\section{References}

Ali, K., Bajracharya, R.M. and Koirala, H.L. (2016). A review of flood risk assessment. International Journal of Environment, Agriculture and Biotechnology, 1(4).

Archfield, S.A. and Vogel, R.M. (2010). Map correlation method: Selection of a reference stream gauge to estimate daily streamflow at ungauged catchments. Water Resources Research, 46(10).

Brunner, G.W. (2016). HEC-RAS River Analysis System. Hydraulic Reference Manual. Version 5.0. Hydrologic Engineering Center, Davis CA, USA.

Cred, C. (2018). Natural disasters in 2017: Lower mortality, higher cost. Tech. Rep. 50, 2018. [Online]. Available: https://cred.be/sites/default/files/CredCrunch.pdf13.

Dangol, S. (2014). Use of Geo-Informatics in Flood Hazard Mapping: A Case of Balkhu River. Nepalese Journal of Geoinformatics, 13: 52-57.

DHM (2018). Climatological Records of Nepal (1988-2017 AD), Kathmandu, Nepal: Department of Hydrology and Meteorology.

Gilard, O. (1996). Flood risk management: risk cartography for objective negotiations. Third IHP/IAHS, George Kovacs Colloquium.

Karki, S., Koirala, M., Pradhanz, A.M.S., Thapa, S., Shrestha, A. and Bhattarai, M. (2011). GISBased Flood Hazard Mapping and Vulnerability to Climate Change Assessment: A Case Study from Kankai Watershed, Eastern Nepal.

MoFALD (2018). Gorkha Municipality, Office of the Municipal Executive. [Online] Available at: http://gorkhamun.gov.np/en

IRDR (2014). Peril Classification and Hazard Glossary (IRDR DATA Publication No. 1), Beijing: Integrated Research on Disaster Risk.

Pratibha Banstola, Bidhan Sapkota 
Doi: https://doi.org/10.33002/nr2581.6853.02033

Regmi, B. and Pandit, A. (2016). Classification of adaptation measures in criteria for evaluation: case studies in the Gandaki River Basin. HI-AWARE Working Paper, 6.

Sharma, K.P., Adhikari, N.R., Ghimire, P.K. and Chapagain, P.S. (2003). GIS-based flood risk zoning of the Khando river basin in the terai region of East Nepal. Himalayan Journal of Sciences, 1(2): 103-106.

UNDP (2010). Disaster Risk Assessment. [Online] Available at: http://www.undp.org

UNISDR (2017). Use of Geospatial Data in Implementing NDRA. United Nations Office for Disaster Risk Reduction, report. [Online] Available at: https://www.preventionweb.net/files/52828_guseofgeospatialdata[1].pdf 